ing the year being about a quarter of a million dollars, from the Philippines but about $\$ 1,000$ and from Hawai

The third item of imports from the islands, consider ing then in the order of magnitude, is manila hemp pine Islands, the total value of the import the Philiparticle being for the year $\$ 7,172,368$, of which $\$ 5,024,770$
came direct from the Philippines.

THE EXHIBIT OF THE DUTCH EAST INDIES AT THE PARIS EXPOSITI

OVER 2,500 square yards, near the Siberian pavilion are devoted to the Dutch East Indian exhibition. It stands the Thee separate buildings; in the cente most remarkable specimens of Hindoo architecture in two models of native houses. The temple is an imposing structure and its decoration is magnificent. The achieved by the aid of moldings cast from the actua in two terraces, one above the other. The bas built second terrace is covered with reproductions of remarkable bas reliefs from a temple which represent scenes in the life of Buddha. They are 200 feet long. Inside of the temple are grouped reprod restoration of the ancient temples, evidently under the direction of the Egsptian priesthood, and, Judging from the inscriptions, with the most serupulous conservatism MEMPHIs.
.

Abydos has been called the cradle of Egypt, but the seat of the first settled monarchy appears to ha ve been the great city of Memphis, just south of modern Cairo, toric king about 4000 B.C. This city wust have been one of the largest of the ancient world, and the ruins of an immense place remained as late as the twelfth century A.D. ; but, owing to the inundations of the Nile, nothing remains of it at the present day but. a lew earth mounds and two colossal statues, which Pyramids and of the great Temple of Ptah, and the west of the Nile, which formed the great cemetery of the city, and among which the famed Pyramids of Gizeh formed the chief. These are surrounded by whole streets of tombs.

The almost every vestige of the large eities which once ex300 miles up the Nile before reaching extensive or mains of temples. The whole valley of the Nile, including the river itself, would appear to have risen since the times of ancient Egypt, so that the Temples of Denderah and Edfu, which will be described in de
Eg PPTIAN COSMOGONY.

The Egyptians imagined the world to be a vast plain suspended in space, of which Egypt, with the Nile running through it, was the center and by tar the most barbarous and uncultivated. Below this plain was stretched out the plain of the nether world, with arother Egypt and Nile almost the counterpart of the sun and moorld, descended in the west and passed back again over the plain of the nether world, rising again in the east. All the spirits
of the departed went to the nether world, and those that were judged worthy of continuing life remained with the same avocations and amusements that them in this world.

It is at Denderah before we come to any considerable remains of a temple. This temple, as it actually the decorations were continued down to the time of the Roman emperors, but the inscriptions show that it was a restoration of an older temple which stood at the same place from the very earliest times. One in-
scription says: "The great building plan of Ant (Denderah) was lound written in ancient charactors on $h$ ide of the times of the successors of Horus." A nother in. scription says that King Totmes III. made a restoration of this monument found described in ancient the Great Pyramid of Gizeh). Thus it appears that

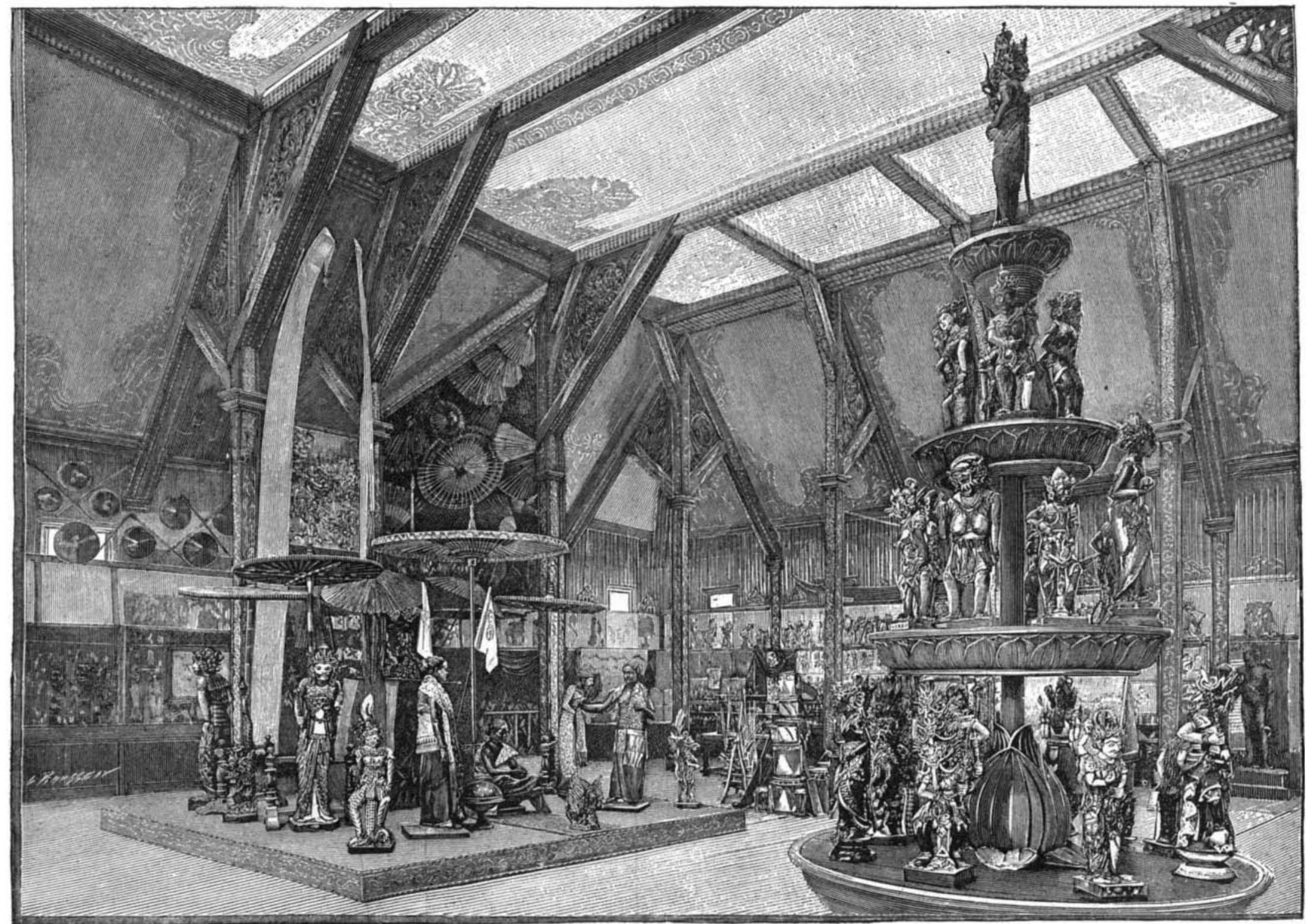

INTERIOR OF THE PAVILION OF THE DUTCH EAST INDIES AT THE PARIS EXPOSITION-EXHIBITION OF IDOLS. sculpture, as shown in our engraving, for which we are

\section{EGYPTIAN TEMPLES.}

By ALexander Patne, F.R.I.B.A.

A MEeting of the Architectural Association took place recently, at which Mr. Payne then read his paper
on "Egyptian Temples," of which the following is a

I think I may say without fear of contradiction that (emples of Exypt we are studying the earliest monuments that exist devoted to religion and erected by what was the most civilized nation of the ancient world.

There is evidence to show that most of the religions of the and had for their unin idea from a common of the powers of nature or as regarding nature as a theater descriptive of divine things. In Egypt it is certain from the monuments themselves and the representations on them that their early worship was dewe have from Eqyptian hieroglyphics a full description of what took place in each room of the temples, where staircases are provided leading up to the flat roofs, so that certain ceremonies might take place in full view
of the heavenls bodies in honor of which the services are held.

When the Greeks and Romanssuccessively conguered Egypt and made it a province of their empires no ligion so similar in to dister to the Egyptian deities were at once adopted as part of the State religion, and vast sums were spent in the the ground, and have had to be dug out quite recently for their complete examination, and are now under There are also extensive remains at Kom Ombos Esneh, Philæ, and other places on the river. It is at ancient Thebes that an idea of the magnificence of ancient Egypt can be best obtained. The ruins of remples and buildings there ex Egypt altogether, if we except the Pyramids, and are far more extensive than auything re maining either at Rome or Athens. The site of the ncient city, being mostly above the level of the inu pon other eities. Thebes datesfrom thioh antiquity. and a few of the more ancient parts of its temples are rom the time of the Eleventh Dynasty, about 250 Dvnasty (about 1400 B.C.), Seti I. and Rameses II. Memphis to Thebes, and the city was embellished with the magnificent temples of which the main. The great group of Karnac alone is nearly mile long and one-third of a mile wide, and comprise avenues of sphinxes. These buildings are mostly far (he limis of a single paper. Moreover, they show in many in of the early temples dedicated to the gods; the monarchs of this period would seem to have been almost intoxicated by the grandeur of the Empire and the extent of its foreign conquests, and the temples are cov-
ered with inscriptions of their own glorious doings,
and, though the credit of them is all ascribed to the gods, the prevailing sentiment seems their own glorification. the Egyptians regarded themseives as the keepers of the ancient times, and were not deviated from in any es sential particular : we may therefore, regard them as models of the ancient temples which existed from the earliest times, and it is irteresting to notice many features in common between them and the Tabernacle ere of Ezekiel and Herod, and also the temples of the plan and arrangement of the great temples of Egypt as there is between the different cathedrals of the Christian Church. This temple of Denderah was dedi-

EGPPTIAN MYTHOLOGY

Egyptain mythology is complicated by the fact that in various localities different names are applied to the same idea. T'he fundamental principle seems to have been to regard the heavenly bodies and powers of in most symbols of the attributes of the Deity and there is the masculine or is a divine Trinity. Flrst by the sun, and called Ra-Harmachis at Heliopolis, Amen-Ra at Thebes, and so on; and in the philosophical idea representing the powers of goodness and ight as opposed to evil and darkness. Secondly, there is the feminine or receptive and maternal principle Hatolized by the moon and stars. and called in the philosophical idea representing truth and faith which keep alive and preserve the powers of goodness in tates of decline symbolized by the night. Finally, there follows the third principle, the new-born day, 
represented by the sun rising again and called Horus and in the philosophical idea representing the resurrection, and regeneration, and the dawn of a new era
of religion and civilization in the world. The ceremonies and processions whici took place in the temples what takes place in nature; each hour aud day bein what takes place in nature; each hour and day being ness and its bursting forth in renewed splendor at the opening of day.
There was probably an entrance court before the Temple of Hathor at Denderah, but if so it has been destroyed, and now one enters directly into a hall or
porch supported by twenty-four columins; this is the It is 143 feet broad, 80 feet deep, and about 50 teet high: it is a most noble apartment of harmonious pro-
portions, and at once strikes the beholder with its
grandeur; the walls are decorated with reliefs record. grandeur; the walls are decorated with reliefs record-
ing the various Pharaohs who built or restored the

Tne ceiling represents the firmament and stars.
Passing through this room, with its beautiful and massive columns covered with inscriptions, we proceed
along the central axis of the temple into the Hall of he Appearance, so called because the statue of Hathor. "the golden-raved." was brought on festive occasions exhibited to the people, who did nut ad vance beyond
the Frout Room : this room is 45 feet 6 inches square, and the ceiling is supported br six columns. There were three sprall rooins on each side of the
Hall of Appearance: one of those on the left side was ointments were preparen for the incense, oils and ointments were preparen for the temple services, as
the inscriptions thereon show. The second roow is ings were placed liere on the festal days. The third room afforded a passage out of the temple. One room on the right, or west side, was called the Silver Room, image and temple utensils of costly materials, as shown
in the inseription, which gives the uses of the room. 'The second room formed an exit from the temple on t." the stair leading to the roof on that side.
Following the main axis of the temple, the next room is called the Hall of the Altar, immediately be hind the Hall of the Appearance. On the left from ascending to the roof. There is also a room on this
side called the Room of Purification, probably used in the preparation of festival ceremonies. On the other
side is another staircase, of short flights, winding rourid a square with landings at the angles and ascending to refer to the great New Year's Festival, on which oc refer to the great New Year's Festival, on which oc-
casion there was a solemn procession of the priests afterward to the roof. On the roof is a small temple, from which the rising sun or the moon and the star of the procession before proceeding down the other staircase. The next room in the center of the temple
axis behind the Hall of the Altar is called the "Hal
of the Cvele of the Gods," or the "Middle Hall." and of the Cycle of the Gods," or the "Middle Hall." an Holy of Holies. This sanctuary is surrounded by a in the services of the temple.
Next to the dwelling of Hathor is " the Chamber of Flames," where the goddess is represented exterminating evil with fire : the next is called the "Throne
Ronm of Rat"-tue Sun-where the Pharaoh (who represented the deity on earth) is shown destroying a crocodile (evil) with his - lance. On the west side are Necklace." where the king is shown presenting a neck
lace to Hathor. In the thickness of the walls of the lace to Hathor. In the thickness of the walls of the trances to which were ingeniously concealed. On the roof were six rooms, three on the east and three on the
west side. devoted to the worship of the slain and risen Osiris, as shown by the inscriptions.

I have pary buildings with ore there are interes ing mortuary buildings with so we of the wost beautifu culptures of Egypt, daing from the time of Seti 1 the great tenples of Karnac and Luxor. It is quite these in detai.

Almost all the temples on the west bank of the rive were mortuary build

\section{ESNEH.}

We next make a stop at Esneh, 484 miles above
Cairo, whereare the remains of tie H postyle or Fron Cairo, where are the remains of tise Hypostyle, or Fron Room, corresponding with the similar apartment a
ready described for Denderah ; it is a very noble spec ready described for Denderah; it is a very noble specicolumns 37 feet high. There are high abiaci over the capitals of the columns, on which rests tie massive archit raves. and again on these the roofing blocks, each
varving block from 22 feet to 26 feet long and 6 feet 6 varping block from 22 feet to 26 feet long and 6 feet
inches wide. It is calculated that there are 110,000 cubic feet of sandstone in this hall alone, and the whole of to these, the hall was founded not later than Totne (Eighteenth Dynasty) and aiterward rebuilt bo th Ptolemies; it was dedicated to the ram-headed KhumRa, one of the representatives of the sun god, and
signifying the union between the rising and setting sun The hall is remarkable for the great beautr of the capirals of its columns, which differ from one another, inspiration from the lotus, palm, and other foliage.

$$
\text { EDFU. }
$$

A few miles above Esneh is Edfu, a little village in which stands the most complete specimen extant of an ancient Egyptian temple. The plan is almost the court surrounded by a colonnade in front of the tem-
ple, entered by a huge pylon or gateway, with two pyramidically-shaped massive towers, which originally formed the main entrance to all Egyptian temples.
There is also a girdle or encircling wall going round the whole temple and forminir an ciater protection,
which probably originally existed round most Eqyptian temples. The pylons in front, or "watch towers" as they are calied in the inscriprions, are 100 feet high large blocks in the pylon ascends to the summit, from which a magnificent view of the winding Nile is ob-
tained. In front of the pylons are four vertical deep which a magnificent view of the winding Nile is ob-
tained. In front of the pylons are four vertical deep
niches, in which were placed the higher fagstaffs, niches, in which were placed the higher flagstaffs,
covered with copper, as the inscriptions tell us, "to covered with copper, as the inscriptions tell us, "to
avert the storms of heaven"; in other words, they avert the storms of heaven"; in other words, they
acted as lightning conductors as well as flagstaffs, a proof of the scientific attainments of the Eypptians. wanting in Denderah) is scacious and open to the sky, paved with flags and surrounded by thirty - two forming a colonnade. The temple itself is sacred to Horus (the sun at his rising). The orientation is ex-
actly the opposite to that at the T'emple of Denderah, the front of which faces nurth, whereas this temple faces south: that is, it faces the position of the sun during the daytime, whereas the one at Denderah,
dedicated to the gods and goddesses of night, faces the position of the sun in the nether world, according to Egyprian ideas, during the night. The temple was rebuilt during the reigns of the Ptolemies, but the in to the plan of the great writing that fell from heaven
to the north of Memphis. It is further stated that the Great Hall was built according to the arrangements of
temples written by Kherheb Iuhotep, son of the god temples written by Kherheb Iumhotep, son of the god
Ptah; this shows that the Egyptians, in the arrangePtah ; this shows that the Egyptians, in the arrange-
ment of their temples, rigidly adhered to the traditions handed down to them trom antiquity and preserved among them in writing. As at Denderah, a
history of this particular temple and a description of the rooms and the uses to which they were put is given
in inscriptions on the walls. From the foundation of the new temple to its completion and the festal entry
of the Deity (B. C. 142) was a period of ninety-five years. The hall following the front roon at Denderah "Hall of the Appearods of the night) is called the "Hall of the Appearance," and the nest room the
"Hacll of the Altar"; then comes the "Hall of the
Cycle of the Gods." I suggest that this is because after the sun has run his course, at nignt he appear in the hall to the worshippers in all his glory. Hathor
being on such occasions called the Golden Beamed being on such occasions called the Gooden Beamed
and the Sun Goddess, and all the powers of heaven are as it were, awake to their duties ; but the correspond Edfu are called the "Festal Hall" and the "Hall of the Repose of the Gods." which seem to indicate the re-
freshment and repose of the deities after the day's work is done. Following the front court, we coure upon the Hypostyle Hall, or front ruom, which forms the first room at Denderah as it now stands. This hall contains, against
the front wall and between the pillars, two little
rooms, one on each side like chapels, which we learn from the inscriptions were intended, the one on the left as an incense chamber to hold the incense and holy water required on religious fest ivals, and the one
on the right as a chamber or safe for the sacred rolls and books of the temple, a catalosue being given on
the walls. The ceiling of this hall is covered with astronomical representations.
A few miles above Edfu the channel of the Nile contracts and passes through a chain of sandstone mountains, which are extensively quarried. Vast
chasms are cut down through the mountains in every dircetion as if they had been sawn, the tool marks of some such inst rument as a saw being plainly visible.
These were the quarries of ancient Thebes, and extend for wiles.

Forty miles above Edfu is the beautiful Temple of Kôm Ombo. The peculiarity of the plan is that it is a
double temple, with twin entrances side by side, and double twin siites of rooms throughout; the left half on ehtry is sacred to Horus, god of the day, and the
right half to Sebek, the crocodile-headed god (a god of the night). Like the other temples we have been ex
amining, there has been a restnration under the Ptoleamining, there has been a restnration under the Ptole-
mies of an ancient building which stood on the site. A short distance farther south brought us to the which are extensive granite quarries. It is said that
all the obelisks, granite blocks, and pillars found in Egypt came from these quarries the labor of working
them, and taking them down to the river and to their
various destivations, must have been almost in various

Above the cataract and quarries is the picturesque island of Philæ. crowned with temples, walls, and
colonnades. The island is about a quarter of a mile
long, and 150 yards broad ; the Temple of Isis, with its accessories, oceupies about half the length of the
island. The remple was built at various times, and owes its charm not only to the vracefulness lof it owes its charm not only to the yracefulness lof it 3
architecture, but also to the beauty of its situation. The inner part of the temple, the tirst apartment of which is au elegant hypostyle consisting of an uncovcolumns on each side, is one of the most beautiful halls in Eqypt, not only on account of its well-balanced proportions and admirable preservation. but especially on being very little perished, conveys a better idea than almost any other example of what the gorgeous effect
of these buildings must have been when their color were fresh and unfaded.
On the east side of the island is an elegant little temple, or pavilion, which goes by the name of four at each end, and half enclosed; it is a favorit subject with painters on account of its elegant form within it are of no importance.-Building Journal.

Guatemalan Cattle Exports. - Under date of June 16 1900, Minister Hunter sends from Guatemala copy tax upon each head of bovine cattle exported from the
Republic to $\$ 70$.
SEIECTED FORMUL E.

1. Jolible Ink.-So-called indelible ink for marking the mark in this case being black. The nitrate aken as a base and alkalies are added. A mixture of this kind, in which sodium hydrate (caustic soda) was used, espleded with great violence, and explosions are which we do not know. This accident has fortunately been rare, and unfortunately lacks convincing explanmodifications are necessary.
In view of the difficult y it would be as well to try the following :
Nitrate of silver........
Infusion of nutgalls
1 ounce.
2 drachws
Water. . . .
8 ounces.

WOODHOUSE'S INDELIBLE INK.

Dissolve the nitrate of silver in 4 ounces of water. In the infusion. Then mix the two liquids.

The infusion of nutgalls is made by pouring 1 ounce

ther watgalls.

A more modern and presumably cheaper indelible convensent, however, in use, as will be seen by the diINDELIBLE INK WITHOUT SILVER.

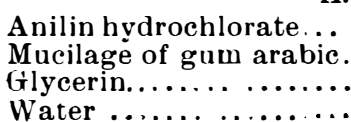
20 parts.

B.

Copper chloride

Ammonium chloride

Mix equal parts of the two solutions just before By pressing the writing with a hot iron the develop-
ment of a black color is hastened. RED INDELIBLE INK.

It is said that by proceeding according to the follow. ing formula, an intense purple-red color may be pro-
duced on fabrics, which is indelible in the customary
sense of the word:

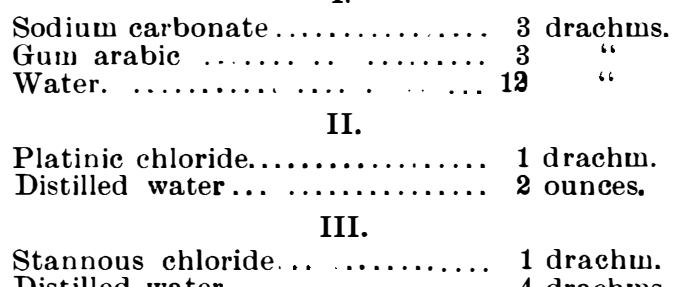

Distilled water.........

Moisten the place to be written upon with No. 1 and rub a warm iron over it until dry; then write with No.
2, and, when dry, moisten with No. 3 . An intense and .

A very rich purple color--the purple of Cassius-may for the platinic chloride in the above formula.-Drug-

A Simple Beetle Trap--Mons. Desire Maes gives the following simple method of making a beetle-trap: Into glass of beer - cover the basin with a newspaper, in the center of which a swall round hole is cut. Place it so that the edges of the paper lie on the floor and the hole attracted by the smell of beer, climb the paper and fall through the hole into the liquid.

Remedy for the Carpet Beetle.-A suburban en destroyer of the carpet beetle. known as Buffalo bug. This insect is, in this locality, rapidly giving the woth points in destructiveness. It eats any textile fabric,
silk, linen or wool, and has defied all known methods of annihilation. Method: Close your apartment or hol or solution of forwaldehyde.-Popular Sience.

Russet Shoe Polish. -

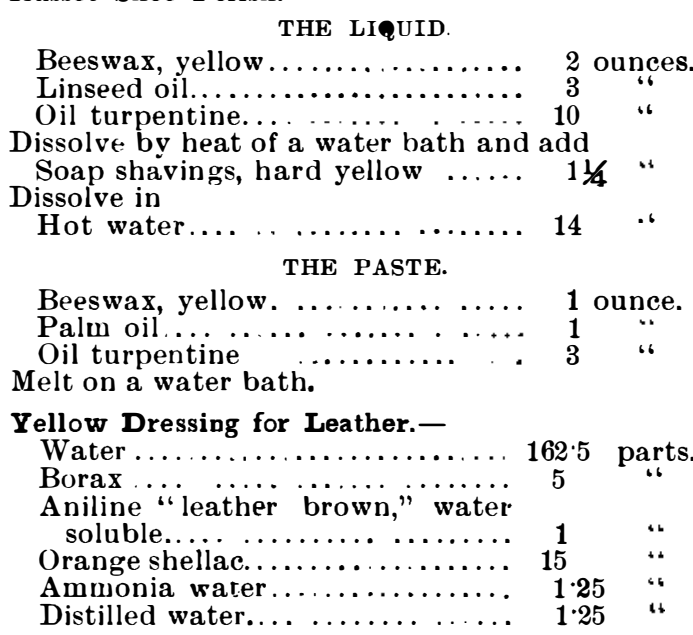

Bring the water to a boil, add the borax and ais-ime, the aniline color (which should quantity at a iron). When the water is boiling actively add the shellac, a little at a time, stirring vigorously while into a clean bessel and allow the mixture to cooldown. Mix the ammonia and water, and when the ruass is quite cool, stir the mixture well in. Other colors (wate soluble) may be used instead of the leather brown, a
ployed.-Pharmaceutical Era. 